\title{
MANDAMUS PROCEEDINGS IN THE FEDERAL COURTS OF APPEALS: A COMPROMISE WITH FINALITY
}

The rule that appellate review in the federal courts may be obtained only from a final judgment ${ }^{1}$ has been the keystone of federal appellate practice since 1789,2 and has been incorporated through statute in most states. ${ }^{3}$ The purpose of the rule is to provide for orderly administration of the judicial process by preventing the unneeded delay and expense caused by multiple appeals in the same suit. ${ }^{4}$ Additionally, the rule has been justified on the belief that trial courts when left to their own devices will normally resolve, or at least render moot, any issue upon which a litigant might desire interlocutory review. ${ }^{5}$ However, the rule has been criticized because of its harshness on both litigants and trial courts when strictly applied, ${ }^{6}$ and it is subject to several statutory exceptions, ${ }^{7}$ including the

128 U.S.C. $\$ 1291$ (1958). It is not within the scope of this paper to discuss what constitutes a final judgment, to consider the dilemma facing the litigant having to make this determination, nor to consider the extensive litigation engendered by the rule. For discussion of these problems, see generally 6 Moore, Federax Practice 110-292 (2d cd. 1953).

2 Cobbledick v. United States, 309 U.S. 323 (1940); Judiciary Act of 1789, I Stat. 73, 83-85.

3 E.g., Cal. Code Civ. Proc. $\$ \S 963,983$; Mass. Gen. Laws ANN. ch. 231, § 109 (1959); Pa. Stat. ANN. tit. 12, § 1092 (1953); Ore. Rev. Stat. \$ 53.010 (1963).

4 DiBella v. United States, 369 U.S. 121, 124 (1962); Cobbledick v. Unitcd States, 309 U.S. 323, 325 (1940); United States v. Bailey, 34 U.S. (9 Pet.) 267, 273 (1835); Canter v. American Ins. Co., 28 U.S. (3 Pet.) 30\%, 318 (1830). But see Crick, The Final Judgment Rule As a Basis for Appeal, 41 YALE I.J. 539, 551 (1932), for the suggestion that the use of the rule has been encouraged mainly by the fear of congestion in the appellate courts.

5 See United States v. 243.22 Acres of Land, 129 F.2d 678 (2d Cir. 1942), cert. denied sub nom. Lambert, Executrix v. United States, 317 U.S. 698 (1943); Perkins v. Endicott Johnson Corp., 128 F.2d 208 (2d Cir. 1942) aff'd, 317 U.S. 501 (1943) (the Supreme Court did not consider the final judgment rule); Crick, supra note 4.

6 See, e.g., Crick, supra note 4, at 560-63.

728 U.S.C. \$ 1292 (1958) states: “(a) The courts of appeals shall have jurisdiction of appeals from: (1) Interlocutory orders of the district courts of the United States, the United States District Court for the District of the Canal Zone, the District Court of Guam, and the District Court of the Virgin Islands, or of the judges thereof, granting, continuing, modifying, refusing or dissolving injunctions, or refusing to dissolve or modify injunctions, except where a direct review may be had in the Supreme Court; (2) Interlocutory orders appointing receivers, or refusing orders to wind up receiverships or to take steps to accomplish the purposes thereof, such as directing sales or other disposals of property; (3) Interlocutory decrees of such district courts or the judges thereof determining the rights and liabilities of the parties to admiralty cases in which appeals from final decrees are allowed; (4) Judgments in civil actions for patent infringement which are final except for accounting.

(b) When a district judge, in making in a civil action an order not otherwise appealable under this section, shall be of the opinion that such order involves a controlling question of law as to which there is substantial ground for difference of opinion and that an immediate appeal from the order may materially advance the ultimate termination 
All Writs Act, which provides: "The Supreme Court and all courts established by Act of Congress may issue all writs necessary or appropriate in aid of their respective jurisdictions and agreeable to the usages and primciples of law."

As is the final judgment rule, the All Writs Act is a direct descendant of the Judiciary Act of $17899^{\circ}$ The power of general superintendence over inferior courts through extraordinary writs has its origin in the earliest common law and was an inherent power of the court of King's Bench. ${ }^{10}$ In Section 13 of the Judiciary Act, Congress attempted to grant to the Supreme Court the power to issue writs of mandamus to all inferior federal courts created by acts of Congress. ${ }^{11}$ This broad grant of supervisory power was curtailed by the decision in Marbury v. Madison, ${ }^{12}$ where the Court ruled that the issuance of such a writ, when the Court does not have original jurisdiction, must be an exercise of appellate jurisdiction or required to enable appellate review. Concurrently with Section 13, Section 14 of the Judiciary Act granted all federal courts, including the Supreme Court, the power to issue extraordinary writs in aid of their respective jurisdictions. ${ }^{13}$ In hight of the wording of the All Writs Act, the special grant of power to the Supreme Court, contained in statutes originating with Section 13 of the Judiciary Act, was eliminated as unnecessary..$^{14}$

The classic requirements for the granting of extraordinary writs, including writs of mandamus, ${ }^{15}$ by a court whose jurisdiction over the dispute is solely appellate, are: (1) issuance of such writ is "in aid of

of the litigation, he sliall so state in writing in such order. The Court of Appeals may thereupon, in its discretion, permit an appeal to be taken from such order, if application is made to it within ten days after the entry of the order; Provided hovever, That application for an appeal hereunder shall not stay the proceedings in the district court unless the district court judge or the Court of Appeals or a judge thereof shall so order."

828 U.S.C. \& 1651 (a) (1958).

O See Judiciary Act of 1789 , $\S \S 13,14,1$ Stat. 73, In re Josephson, 218 F.2d 174 (1st Cir. 1954).

10 See generally 51 L.R.A. 33 (1901).

11 I Stat. 73, 81 (1789); In re Josephson, 218 F.2d 174, 177 (1st Cir. 1954).

125 U.S. (1 Cranch) 137 (1803).

181 Stat. 73, 81 (1789).

14 See Reviser's note to 28 U.S.C. \& 1651 (1958).

15 Traditionally, writs in aid of appellate jurisdiction were used to limit inferior courts to their prescribed jurisdictions, and require exercise of their authority when they have a duty to do so. See Roche v. Evaporated Milk Assn., 319 U.S. 21, 26 (1943). It is not the purpose of this paper to discuss the technical differences between writs of mandamus and prohibition. It is possible through drafting of a petition for extraordinary relief to ask for one or the other, or both in the alternative, and such distinctions do not seem to affect their use as vehicles for review of interlocutory orders. See generally Sunderland, The Problem of Appellate Review, 5 TEXAS L. REv. 127 (1926), suggesting that distinct forms of extraordinary writs be replaced by a single form for appeal. 
appellate jurisdiction"; ${ }^{16}$ (2) the aggrieved party has no adequate alternative; ${ }^{17}$ (3) the circumstances are otherwise extraordinary; ${ }^{18}$ and (4) the power is not to be exercised to circumvent the policy against review of interlocutory orders prior to appeal from a final judgment. ${ }^{10}$ Of these requirements, the major limitation on the court's power is that issuance must be "in aid of appellate jurisdiction." Although the cases are irreconcilable, ${ }^{20}$ prior to 1957 the courts of appeals generally took a narrow view of what uses were in aid of appellate jurisdiction. Several circuits limited use to those situations where the trial court's determination of an interlocutory matter, such as an order of transfer to a more convenient district outside of the circuit, would preclude or obstruct review by the court of appeals in whose circuit the trial court was located. ${ }^{21}$ Other circuits found a use in aid of appellate jurisdiction only when the challenged trial court action could not be corrected through an alternative mode of review such as appeal from a final judgment. ${ }^{22}$ In spite of indications by the Supreme Court that "in aid of appellate jurisdictions" should be more hberally construed in order to give the courts of appeals broad discretionary powers to issue writs of mandamus, ${ }^{23}$ the circuit courts, rather than recognizing that they had a power which could be exercised in their discretion, continued to speak in terms of lack of power. ${ }^{24}$

\footnotetext{
16 See, e.g., Roche v. Evaporated Milk Assn., 319 U.S. 21, 25 (1943).

17 See, e.g., Ex parte Fahey, 332 U.S. 258 (1947); Ex parte Harding, 219 U.S. 363 (1911).

18 See, e.g., In re Josephson, 218 F.2d 174, 183 (1st Cir. 1954).

10 See, e.g., Roche v. Evaporated Milk Assn., 319 U.S. 21, 30 (1943).

20 See note, 52 Mich. L. REv. 1065 (1954).

21 See, e.g., In re Josephson, 218 F.2d 174 (1st Cir. 1954). Contra, Paramount Pictures v. Rodney, 186 F.2d 111 (3d Cir.), cert. denied, 340 U.S. 953 (1951) (review of trial court's refusal to consider motion to transfer to a more convement district); Ford Motor Co. v. Ryan, 182 F.2d 329, 330 (2d Cir.), cert. denied, 340 U.S. 851 (1950) (review of order refusing transfer to another more convenient district).

22 Paramount Pictures v. Rodney, 186 F.2d 111 (3d Cir.), cert. denied, 340 U.S. 953 (1951) ; Ford Motor Co. v. Ryan, 182 F.2d 329 (2d Cir.), cert. denied, 340 U.S. 851 (1950). But see Gulf Research \& Dev. Co. v. Leahy, 193 F.2d 302 (3d Cir. 1951), aff'd, 344 U.S. 861 (1952). In Paramount Pictures v. Rodney, supra, the court, in reviewing the trial court's refusal to rule on a motion to transfer to another district, found appeal from a final judgment to be inadequate due to the probability that the defendant, should he lose on the merits, could not show prejudice on appeal. In Gulf Research \& Dev. Co. v. Leahy, supra, the court, while declining to review the propriety of the trial court's refusal to transfer to another district, held that appeal from a final judgment was adequate although the trial may at that time be proved to have been unnecessary.

23 See, e.g., Roche v. Evaporated Milk Assn., 319 U.S. 21 (1943), discussed in note 24 infra; Ex parte Peru, 318 U.S. 578 (1943) (review of trial court's refusal to dismiss aclmiralty proceeding in rem against ship owned by the government of Peru); Los Angeles Brush Mfg. Corp. v. James, 272 U.S. 701 (1927) (review of assignment to master of patent case).

24 See, e.g., Great Northern Ry. v. Hyde, 238 F.2d 852 (8th Cir. 1956), aff'd on rehearing, 245 F.2d 537 (8th Cir. 1957) (the court granted rchearing due to the decision in LaBuy v.
} 
In 1957, the Supreme Court decision in La Buy v. Howes Leather ${ }^{25}$ heralded the expanded use of the writ of mandamus by courts of appeals. In that decision, the Supreme Court eliminated any doubt about the very broad meaning of " $\mathrm{m}$ aid of appellate jurisdiction," and stressed the discretionary aspect of the circuit court's exercise of its power. ${ }^{26}$

The purpose of this Comment is to attempt to discover a pattern in the courts of appeals' decisions to review trial court actions through proceedings for mandamus subsequent to $L a B u y$, and to discuss the possible use of mandamus proceedings to test the trial court's determination of personal jurisdiction. ${ }^{27}$

\section{I}

\section{THE STATE OF THE LAW-La Buy v. Howes Leather}

To the extent that $L a$ Buy discussed the circuit courts' power to issue writs of mandamus, the decision elimmated one source of confusion. However, $L a$ Buy perpetuated the uncertainty by transferring it to the question of whether, having reviewed the trial court's action, a court should exercise its discretion and issue the writ. More importantly, La Buy failed to discuss the factors which slould be considered by a circuit court in initially determining whether to review the trial court's action at all.

In sustaiming the court of appeals' power to issue writs of mandamus compelling a district court judge to vacate his order referring antitrust

Howes Leather Co., 352 U.S. 249 (1957) but declined to exercise its discretion to issue a writ of mandamus); In re Josephson, 218 F.2d 174 (1st Cir. 1954); Southern Pac. Co. v. United States Dist. Ct. for No. Dist. of Cal., 190 F.2d 735 (9th Cir. 1951). Note that in Roche v. Evaporated Milk Assn., 319 U.S. 21 (1943), the court suggested that a circuit court's power to issue extraordinary writs demanded only that the case be within the circuit court's appellate jurisdiction even though no appeal had been perfected, and that any extraordinary writ issued under such circumstances would be in aid of appellate jurisdiction. The Court proceeded, however, to rule that the facts of the case did not present a proper case for exercise of the circuit court's discretion as the district court's actions did not "thwart appellate review" and that "while a function of mandamus in aid of appellate jurisdiction is to remove obstacles to appeal, it may not appropriately be used merely as a substitute for the appeal procedure prescribed by the statute." Id. at 26. See also, Wolfson, Extraordinary Writs in the Supreme Court Since Ex parte Peru, 51 Corun. L. REv. 977 (1951).

25352 U.S. 249 (1957).

26 Additionally, the retirement in 1962 of $\mathrm{Mr}$. Justice Frankfurter, a most ardent and outspoken advocate of the final judgment rule, may result in a more hiberal attitude in the federal courts toward the use of mandamus proceedings. Examples of Justice Frankfurter's views on the rule of finality are contained in DiBella v. United States, 369 U.S. 121 (1961) ; Ex parte Peru, 318 U.S. 578 (1943) (dissent); Cobbledick v. United States, 309 U.S. 323 (1940).

27 This Comment is limited to discussion of civil cases.' Similar problems may, of course, arise concerning extraordinary proceedings in connection with criminal cases. See, e.g., In re United States, 286 F.2d 556 (1st Cir. 1961), rev'd sub nom. Fong Foo v. United States, 369 U.S. 141 (1962). 
cases to a master, the court discussed two distinct areas of consideration bearing upon the issuance of writs of mandamus by circuit courts.

\section{A. The Power of the Courts of Appeals}

The Court reaffirmed that proper judicial admimistration requires supervisory control of the district courts by the courts of appeals and that in proper circumstances such supervisory authority might be exercised through extraordinary means. ${ }^{28}$ The Court did not hold that this supervisory authority alone was sufficient justification for exercise of the circuit court's discretion to issue writs of mandamus. Further, the Court made it clear that the circuit courts have the "naked power"20 to issue extraordinary writs whenever they could at some future stage of the litigation exercise jurisdiction to review on appeal from a final judgment. In such a situation, issuance of a writ of mandamus would be "in aid of appellate jurisdiction," and the requirements of the All Writs Act would in that regard be satisfied. ${ }^{30}$ However, the Court indicated that its recogmition of the circuit court's power was not an authorization of indiscriminate use of the writ of mandamus to circumvent the final judgment rule. ${ }^{31}$

\section{B. The Discretionary Use of the Writs}

The Court emphasized the discretionary nature of the court of appeals' election to exercise its "naked power." In light of the factual situation of La Buy, several factors were considered pertinent in evaluating the quahty of the trial court's action to determine whether a writ of mandainus was appropriate.

Although the court of appeals had found the district court's reference to a master to be "beyond the court's power," not in terms of the district court's lack of power, but rather in terms of the trial court's "abuse of power" and "clear abuse of discretion." La Buy sohdly implants this term, "abuse of discretion," into the already confused area of extraordinary writs. ${ }^{34}$ It slould be clear, however, that

28352 U.S. at $256,259-60$.

$20 \mathrm{Id}$. at 255 .

30 Ibid.

31 Ibid.

32 Howes Leather Co. v. La Buy, 226 F.2d 703, 705-06 (7th Cir. 1955).

33352 U.S. at $255-59$.

34 See Hvass v. Graven, 257 F.2d 1 (8th Cir.), cert. denied, 358 U.S. 835 (1958). In La Buy the court cited in support of its "abuse of discretion" language, Bankers Life \& Cas. Co. v. Holland, 346 U.S. 379 (1953), in which the Court in refusing to review a trial court's order of severance and transfer under 28 U.S.C. $\S 1406$ (a), found no abuse of discretion, but rested its decision upon the trial court's "power" to so transfer and the availability of review from a final judgment. 
if the Court did not equate "clear abuse of discretion" with a lack of power, it at least found the same considerations common to both when it concluded that reference to a master was, under the circumstances, a demial of the litigant's right to trial before the court, and that such abuse of discretion amounted to an abdication of judicial function. ${ }^{35}$ The Court emphasized this view when, in quoting from a prior decision, ${ }^{38}$ it said, " [ $[W]$ here the subject concerns the enforcement of the ... rules which by law it is the duty of this court to formulate and put in force', mandamus should issue to prevent such action thereunder so palpably improper as to place it beyond the scope of the rule invoked."

II

THE APPELLATE COURTS' REACTION TO La Buy

\section{A. The Power of the Courts of Appeals}

Since $L a B u y$, the courts have demonstrated their recognition that responsibility to supervise the activities of the district courts may be discharged through proceedings for mandamus. ${ }^{37}$ They are aware of their power to review through such proceedings when the trial court acts complamed of might at a future stage of the litigation be reviewable. ${ }^{38}$ The difficult question facing a court is whether the controversy presented is such that it demands exercise of the court's discretionary power to review. Certainly it would not appear that supervisory authority in and of itself is sufficient justification. ${ }^{39}$ To so conclude would be to say that because the court has the power, it should exercise it. The courts must proceed to the more difficult and controversial area, that of weighing the quality of the trial court's action to determine whether the particular

35352 U.S. at 256. The Court found that the case was not "exceptional" as required by Federal Rule $53(\mathrm{~b})$, and therefore was beyond the scope of the Rule's limited grant of power to deny a trial before the court.

${ }^{86}$ Los Angeles Brush Mfg. Corp. v. James, 272 U.S. 701 (1927).

37 See, e.g., Atlass v. Miner, 265 F.2d 312 (7th Cir. 1959) (supervision over discovery rules in admiralty proceeding), aff'd, Miner v. Atlass, 363 U.S. 641 (1960) (the Court considered only the court of appeals' supervisory authority and not the propriety of extraordinary review).

88 Compare In re Josephson, 218 F.2d 174 (1st Cir. 1954), with In re Union Leader Corp., 292 F.2d 381 (1st Cir. 1961). In In re Union Leader the court recognized its power to issue a writ of inandaunus but refused to exercise its discretion to do so after a hearing on the merits of petitioner's claim of bias of the trial judge. The court found exceptional circumstances in the petitioner's claim which called for circunivention of the finality rule. But see CMAX, Inc. v. Hall, 290 F.2d 736 (9th Cir. 1961) (the court concluded it was without authority to grant an extraordinary writ because of the availability of an alternative nethod of review and that ouly when appellate review would be defeated if the writ does not issue is mandamus proper).

39 The author has found no cases which have justified the use of a writ of nuandanus solely on such grounds. 
controversy may best be resolved through extraordinary procedures. In spite of the broad grant of power contained in the All Writs Act, the courts of appeals have limited themselves to a degree in the use of mandamus proceedings by taking many of the pre- $L a$ Buy arguments concerning their power to grant the writ and applying them in determining whether they should in the exercise of their discretion issue the writ.

\section{B. The Discretionary Use of the Writs}

The real uncertainty in the field of federal mandamus lies in the area of discretion. The courts continue to obscure and confuse the matter by speaking in terms of the "trial court's abuse of discretion," "lack of trial court power and jurisdiction;" and "nonavailability or ineffectiveness of alternative methods of appellate review."

Although mandamus was historically a legal remedy, the courts in deciding to exercise their discretion are influenced by equitable principles. ${ }^{40}$ The equitable nature of the remedy creates an almost insurmountable barrier to dogmatic formulations in this area of the law. Indeed, it has been suggested that the best that can be said is that the courts should consider the importance of the trial court action questioned, the relative ease and economy of review via extraordinary procedure, and whether such review will aid in the ultimate termination of the litigation. ${ }^{41}$

The courts of appeals have repeatedly stated that exercise of appellate review through proceedings for writ of mandamus is not to be used as a substitute for appeal from a final judgment. ${ }^{42}$ The final judgment rule forbids "piecemeal disposition on appeal of what for practical purposes is a single controversy." 43 Its objective is to economize the time of the courts of appeals by providing that all issues of a controversy should be reviewed together after the final judgment. Whether the circuit court chooses to issue the writ or not, if it hears the petition for mandamus it lias circumvented the rule of finality. The courts have not, however, been able to consistently distinguish between peremptory refusal to review by denial of a motion to petition, and refusal to issue the writ after a hearing on the petition. ${ }^{44}$ The extraordinary procedure is initiated by a motion to the circuit court to petition for writ of mandamus. The motion is granted by the court's issuance to the trial court of an order to show cause why mandamus should not issue. Review of the trial court's action takes place upon a hearing on the petition, and it is at this stage of the proceedings

40 Duncan Townsight Co. v. Lane, 245 U.S. 308, 311-12 (1917).

41 Louisert \& Hazard, Cases on Pleading and Procedure 1241 (1962).

42 See, e.g., Schlagenhauf v. Holder, 321 F.2d 43 (7th Cir. 1963), cert. granted, 375 U.S.

984 (1964) (review of discovery order of physical examination).

43 Cobbledick v. United States, 309 U.S. 323, 325 (1940).

44 See, e.g., Schlagenhauf v. Holder, 321 F.2d 43 (7th Cir. 1963). 
that circumvention of the rule of finality occurs. The petition may be granted by issuance of the writ, or denied and the order to show cause discharged..$^{45}$ Courts have on occasion, while reviewing the trial court's interlocutory order, acknowledged their inability to circumvent the rule of finality as a reason for refusing to grant the writ of mandamus. ${ }^{46}$ If the appellate court grants the motion to petition, however, and holds a hearing, the court has circumvented the rule of finality. ${ }^{47}$

In weighing the factors which may lead to the suitability of extraordinary rehef, the courts are hampered by a distaste for the extraordinary procedure, and a desire not to interfere with the proceedings in the trial court. ${ }^{48}$ At least one court has been able to draw a distinction between the degree of appellate court interference in a hearing on petition for writ of mandamus, and a hearing on appeal after the court of appeals had "suggested," upon considering a motion to petition, that the trial court might certify the question, and the trial court had so complied..$^{49}$ Althougl there may be a technical distinction, both proceedings equally interrupt the trial court proceedings and consume the time of the court of appeals. When a court does hear a petition, the prevailing practice nevertheless calls for a denial of the writ, the court assuming that the trial court will comply with its wishes contained in the opinion issued after the hearing on the petition..$^{50}$

The courts of appeals also indicate that a writ of mandamus is reserved for extraordinary circumstances. ${ }^{51}$ Such a statement contributes nothing to the clarity of the situation, but is merely begging the question. The factors which will lead a court to exercise its discretion are the same factors which will lead the court to find an "extraordinary situation" suitable for the use of a writ of mandamus.

\footnotetext{
45 See, e.g., SUP. Cr. R. 31, 3D CrR. R. 19, 7Tr CIR. R. 19a.

46 See, e.g., Schlagenhauf v. Holder, 321 F.2d 43 (7th Cir. 1963).

$47 \mathrm{It}$ is impossible for a court of appeals to consider whether a particular case presents facts justifying exercise of discretion in issuing a writ of mandamus without in some measure reviewing the trial court's interlocutory order.

${ }^{48}$ Cf. In re Humble Oil \& Ref. Co., 306 F.2d 567 (5th Cir. 1962) (per curiam).

40 Compare In re Humble Oil \& Ref. Co., 306 F.2d 567 (5th Cir. 1962) (per curiam), with Humble Oil \& Ref. Co. v. Bell Marine Serv., Inc., 321 F.2d 53 (5th Cir. 1963).

50 See, e.g., Holub Ind., Inc. v. Wyche, 290 F.2d 852 (4th Cir. 1961) (review of trial court's determination to proceed when venue improperly laid); New York, S. \& W. R.R. v. Follmer, 254 F.2d 510 (2d Cir. 1958) (review of trial court's reference to administrative agency). But see Swindell-Dressler Corp. v. Dumbauld, 308 F.2d 267 (5th Cir. 1962) (mandamus issued to facilitate petition for certiorari to the Supreme Court).

${ }^{51}$ See, e.g., Lummus Co. v. Commonwealth Oil Ref. Co., 297 F.2d 80 (2d Cir. 1961) (court issued mandamus to prevent relitigation of the issue of whether certain portions of a contract were subject to arbitration when such issue was previously determined by another court of appeals); Fisher v. Delehant, 250 F.2d 265 (8th Cir. 1957) (court refused to grant mandamus to trial court to vacate part of discovery order denying discovery of court files).
} 
A major consideration which affects the propriety of an appellate court's use of a writ of mandamus is the existence of an effective alternative such as review from a final judgment, ${ }^{52}$ or the possibility that upon motion of the aggrieved party the trial court might certify the question to allow interlocutory appeal. ${ }^{53}$ At least two circuits, in denying motions to petition, have said that if the aggrieved party has not moved for certification in the trial court, it would be improper for the appellate court to hear a petition for writ of mandamus. ${ }^{54}$ Such an approach might be justified upon the theory of exhaustion of remedies. Its main appeal, however, seems to stem from the appellate court's respect for the lower tribunal, and a desire not to interfere unless the trial court has conclusively shown the necessity for such interference.

It is clear that expense and inconvenience are irrelevant to a determination of the adequacy of appeal from a final judgment or the presence of an "extraordinary situation." Where a hitigant may be forced to conduct his case in a distant and inconvenient jurisdiction, the availability of an appeal from a final judgment is found sufficient. ${ }^{56}$ Even where it was argued that the trial court lacked jurisdiction over person or subject-matter, the parties were forced to hitigate the controversy on the merits although it was hkely that a second trial on the merits would be required. The expense and inconvenience to the aggrieved party were found not to be sufficient justification for the exercise of discretion to review..$^{57}$ It is clear, however, the trial court in such a situation entertains

52 See, e.g., Bartsch v. Clarke, 293 F.2d 283 (4th Cir. 1961) (no attempt by petitioner to comply with statutory requirements for judicial review); Regec v. Thornton, 275 F.2d 801 (6th Cir. 1960) (trial court order striking answer of third-party defendant and severing issues between plaintiff and defendant and between defendant and third-party was subject to review on appeal from final judgment).

53 In re Humble Oil \& Ref. Co., 306 F.2d 567 (5th Cir. 1962) (per curiam).

${ }^{54}$ All State Ins. Co. v. Umited States Dist. Ct. for E. Dist. of Mich., 264 F.2d 38 (6th Cir. 1959) (denial of motion to dismiss cross-complaint); In re Hunble Oil \& Ref. Co., 306 F.2d 567 (5th Cir. 1962) (per curiam).

55 See, e.g., Bankers Life \& Cas. Co. v. Holland, 346 U.S. 379 (1953); Roche v. Evaporated Milk Assn., 319 U.S. 21 (1943); Massey-Harris-Ferguson, Ltd. v. Boyd, 242 F.2d 800 (6th Cir. 1957); Black v. Boyd, 248 F.2d 156 (6th Cir. 1957). In Black v. Boyd the court reviewed the trial court's determination that defendant's cross-claim did not entitle him to a jury trial and directed the trial court to vacate so much of its order striking the defendant's demand. The trial court proceeded to order the trial before the court of all equitable issues raised by the complaint prior to trial of the legal issues before a jury. The court in the second Black v. Boyd, 251 F.2d 843 (6th Cir. 1958), refused to review this action of the trial court since review on appeal from a final judgment was an adequate remedy even if the trial court had misconstrued the court's mandate in the first Black $v$. Boyd.

50 See, e.g., Great Northern Ry. v. Hyde, 245 F.2d 537 (8th Cir.), cert. denied, 355 U.S. 872 (1957).

57 See note 60 infra. 
a dispute which it is without the "power" to entertain. ${ }^{58}$ Not only are the presence of expense and inconvenience insufficient to compel interlocutory review, the lack of these factors does not preclude interlocutory review through extraordinary means when a trial court has, through the use of a pre-trial order, effectively denied the hitigant his right to a trial. ${ }^{68}$

In considermg whether they should exercise their discretion and issue writs of mandamus, the courts also consider whether the trial court's action is in excess of its "jurisdiction." In using the term "jurisdiction" in this context, the courts are referring not to jurisdictional problems over person or subject-matter. ${ }^{60}$ Rather, although the cases are not entirely consistent, the courts are speaking of a trial court's "power" to take a particular step under the federal rules once jurisdiction over the parties and the subject matter has been estabhshed. ${ }^{61}$ When a trial court transferred an action to another more convenient district pursuant to Section 1404(a) of the Judicial Code, ${ }^{62}$ without affording the plaintiff a hearing prior to transfer as required, it was an action beyond the court's "power" and mandamus was appropriate. ${ }^{63}$ Similarly, where the trial court transferred the case under section 1404 (a) to a district where the action could not have origmally been brought, it was beyond its "power" under the

58 See note 61 infra. It is of course true the litigant might avoid all such expense and inconvenience by refusing to contest the merits of the dispute and appealing from the final judgment, but the possible sacrifice of his case on the merits does not make this an especially attractive alternative to the defendant. If the courts are correct in their refusal to review immediately in this situation, it is difficult to understand why the availability of an appeal from a final judgment is not also sufficient when a trial court has transferred to a district in which the action could not have been brought originally. See notes 62, 64 infra.

59 Padovani v. Bruchhausen, 293 F.2d 546 (2d Cir. 1961). It is difficult to understand why the dilemma facing the aggrieved party under these circumstances is any more extraordinary than the dilemma facing the defendant who in good faith believes the trial court lacks personal jurisdiction. See note 58 supra.

60 Allstate Ins. Co. v. United States Dist. Ct. for E. Dist. of Mich., 264 F.2d 38 (6th Cir. 1959) (per curiami) (refusal to review trial court's determination as to subjectmatter jurisdiction); Smith's Transfer Corp. v. Barksdale, 259 F.2d 498 (4th Cir. 1958) (refusal to review trial court's determination of subject-matter jurisdiction); Electrical \& Musical Ind. Itd. v. Walsh, 249 F.2d 308 (2d Cir. 1957) (per curiam) (refusal to review trial court's determination of personal jurisdiction to subpoena duces tecum); Massey-HarrisFerguson, Ltd. v. Boyd, 242 F.2d 800 (6th Cir. 1957) (refusal to review trial court's determination of personal jurisdiction over a Canadian corporation).

61 See, e.g., International Prod. Corp. v. Koons, 325 F.2d 403 (2d Cir. 1963) (trial court lack of power to restrain use of evidence obtained otherwise than through the court's processes).

62 "For the convenience of parties and witnesses, in the interest of justice, a district court may transfer any civil action to any other district or division where it might have been brought." 28 U.S.C. § 1404 (a) (1958).

63 See, Swindell-Dressler Corp. v. Dumbauld, 308 F.2d 267 (3d Cir. 1962) (trial court denial of "procedural due process of law"). 
rules. ${ }^{64}$ However, if a court is entertaining an action over which either subject-matter or personal jurisdiction is in doubt, not only do the courts consider mandamus inappropriate, but review by a hearing on the petition is not available. ${ }^{65}$

The courts of appeals continue to speak of a trial court's "abuse of discretion" in considering the propriety of relief through mandamus." A mere error im the determination that another district is more convenient and transferring the case under section 1404 (a) is not sufficient.77 At least one court has suggested that even an abuse of discretion is not sufficient to merit issuance of a writ of mandamus when an appellate court is able to review upon appeal from a final judgment the factors which led to the trial court's determination that another district was more convement. ${ }^{68}$ Another court has indicated that a possible "abuse of discretion" is not, standing alone, sufficient to require even a hearing on a petition for writ of mandamus. ${ }^{60}$ It is apparent that an abuse of discretion will be found only in the following situations: when the trial court's action results in deprivation of a substantial right of the aggrieved party, such as his right to a jury trial, ${ }^{70}$ trial before a court, ${ }^{71}$ trial before an

64 See, Barrack v. Van Dusen, 309 F.2d 953 (3d Cir. 1962), rev'd Van Dusen v. Barrack, 84 S.Ct. 805 (1964). The Supreme Court held that the transferee district was one where the action might have been brought. The Court did not question the use of mandamus as a method of interlocutory review.

65 See note 60 supra. In Massey-Harris-Ferguson, Ltd. v. Boyd, 242 F.2d 800 (6th Cir. 1957), the court suggested that in light of cases such as International Shoe v. Washington, 326 U.S. 310 (1945), the law concerning personal jurisdiction was uncertain. It was therefore difficult to know what facts were necessary to sustain personal jurisdiction. The court concluded that the trial court should be afforded all opportumity to resolve the question, with the possibility that the facts might be more fully developed during trial, and that review should await a final judgment. If International Shoe has introduced a degree of ambiguity into questions of personal jurisdiction due to "mimimum contacts" as opposed to the power concepts of Pennoyer v. Neff, 95 U.S. 714 (1877), the likelihood is greater now that a trial court's determination on this question may be in error and all litigation of the merits wasted should an appeal be taken from a final judgment. While it is true the appellate court will have been spared the separate review proceedings, the trial court will be burdened with relitigation of the inerits.

66 See, e.g., Schlagenhauf v. Holder, 321 F.2d 43 (7th Cir. 1963), cert. granted, 375 U.S. 983 (1964) (review of trial court order of physical examination, mandamus denicd); Burgess v. Williams, 302 F.2d 91 (4th Cir. 1962) (review of trial court's order of reference. Mandamus demed).

67 E.g., Chemical \& Indus. Corp. v. Druffel, 301 F.2d 126 (6th Cir. 1962).

68 Cf. Great Northern Ry. v. Hyde, 245 F.2d 537, 538 (8th Cir.) (dissenting opinion), cert. denied, 355 U.S. 827 (1957).

69 Beneke v. Weick, 275 F.2d 38 (6th Cir. 1960).

70 Dairy Queen v. Wood, 369 U.S. 469 (1962); Burgess v. Williams, 302 F.2d 91 (4th Cir. 1962) (reference to a master, mandamus demied after review of the trial court's action); In re Watkins, 271 F.2d 771 (5th Cir. 1959) (reference to a master). But see Institutional Drug Dist., Inc. v. Yankwich, 249 F.2d 566 (9th Cir. 1957) (court of appeals refused to conclude whether the aggrieved party was entitled to trial before a jury, reserving the question for an appeal from a final judgment should one be filed).

71 La Buy v. Howes Leather, 352 U.S. 249 (1957). 
impartial tribunal; ${ }^{72}$ or when the trial court's action is beyond the "power" of the court, such as transferring the action to a more convenient district where it could not have been brought originally, ${ }^{73}$ transferring to a more convenient district without a hearing, ${ }^{74}$ requiring litigation of issues already litigated, ${ }^{75}$ or limiting the defendant's use of evidence obtained without the aid of discovery procedures. ${ }^{76}$

The courts liave also found the writ of mandamus appropriate when a trial court has refused to exercise its discretion, as in a refusal to consider a motion to transfer, although the courts have refused to instruct the trial court as to how such discretion slould be exercised. ${ }^{77}$ When a trial court's order of a stay has been in effect a surrender of the controversy to a state court when the federal court is competent to hear the case, the courts of appeals have found an appropriate use for writs of mandamus. ${ }^{78}$

\section{III}

\section{A SENSIBLE APPROACH}

The confusion and inconsistency in the courts of appeals' decisions indicates that a reevaluation of the use of mandamus is in order. The final judgnient rule does not stand alone in its purpose of simphifying the judicial process in order that controversies may be decided in an orderly fashion without undue delay. The All Writs Act pursues the same goal. The courts then are engaged in meaningless inquiry when they consider whether the trial court has "abused its discretion" and acted beyond its "power" or whether an appeal from a final judgnient is either available or adequate. Sucl considerations are inadequate under $L a B u y$ in the determination of whether the writ should issue. They are even more inadequate in aiding in the determination of whether to review at all. Instead, the courts should consider whether the use of extraordinary review, which nuay or may not terminate im actual issuance of the writ,

72 In re Union Leader Corp., 292 F.2d 381 (1st Cir.), cert. denied, 368 U.S. 927 (1961) (petition for writ of nuandanius denied after a hearing on the petition); United States $v$. Ritter, 273 F.2d 30 (10th Cir. 1959) (per curiam); Occidental Petroleum Corp. v. Chandler, 303 F.2d 55 (10th Cir. 1962) (per curiam), cert. denied, 372 U.S. 915 (1963).

73 See note 64 supra.

74 See note 63 supra.

75 Lummus Co. v. Commonwealth Oil Ref. Co., 297 F.2d 80 (1961).

76 International Prod. Corp. v. Koons, 325 F.2d 403 (2d Cir. 1963). The court treated an iniproper appeal from trial court's order as a motion to petition for extraordinary relief, reviewed the trial court's action and expressed its opinion that upon hearing of a petition, mandamus would be appropriate but that such proceedings would not be required as the trial court would probably comply without actual issuance of the writ.

77 Paramount Pictures v. Rodney, 186 F.2d 111 (3d Cir.), cert. denied, 340 U.S. 953 (1951).

78 Mach-tronics, Inc. v. Zirpoli, 316 F.2d 820 (9th Cir. 1963); Lutes v. United States Dist. Ct. for W. Dist. of Okla., 306 F.2d 948 (10th Cir.), cert. denied, 371 U.S. 941 (1962). 
will aid in attaining the goal of both the doctrine of finality and the All Writs Act-insuring efficient functioning of the judicial system so that the parties may obtain a timely decision and terminate the litigation. ${ }^{70}$ Only when this question is answered in the affirmative should interlocutory review through hearing on a petition for writ of mandamus be appropriate. It is obvious that such an approach does not presage the destruction of the final judgment rule but rather demands a compromise between that doctrine and the availability of review through a hearing on a petition for a writ. Just as indiscriminate use of the extraordinary procedure can create a burden upon the courts of appeals, the rigid application of the final judgment rule will result not only in undue expense to the hitigants but in a burden upon the already overcrowded trial courts where the merits of the action must be tried twice should the trial court's determination be erroneous..$^{80}$ Additionally, a burden is cast on those many litigants for whoin determination of their controversy is delayed due to crowded dockets in the trial courts. It should be noted that the appellate courts are able to mitigate the undesirable results in both directions and consequently should consider not only their own burdens, but those of the trial courts as well.

Such an approach, with one notable exception, ${ }^{81}$ gives a degree of consistency to the past decisions which cannot be found by discussing the problem in other terins. It explains why courts are reluctant, except when the litigant is being denied a substantial riglit, sucl as his right to trial before an impartial tribunal, to review by extraordinary means interlocutory orders on such matters as discovery, ${ }^{82}$ pre-trial ${ }^{83}$ severance, ${ }^{84}$ or consolidation, ${ }^{85}$ which probably will be moot by the time of

79 It is quite possible that this is but another way of stating Professors Louisell's and Hazard's suggestion for appellate court considerations. See note 41 supra.

80 There have been indications that some conservatism in the availability of revicw through extraordinary proceedings may stem from incompleteness of the record at such stage of the proceedings. See Massey-Harris-Ferguson, Ltd. v. Boyd, 242 F.2d 800 (6th Cir. 1957). In any circumstances, of course, the record will be more complete upon an appeal from a final judgment, but the cost in terms of unneeded hitigation is a severe price to pay for such a record.

81 Circuit court's refusal to review trial court's determination of the question of personal jurisdiction. See notes 60, 65 supra.

82 E.g., Byram Concretanks, Inc. v. Meaney, 286 F.2d 170 (3d Cir. 1961) (per curiam); Fisher v. Delehant, 250 F.2d 265 (8th Cir. 1957). But see Schlagenhauf v. Holder, 321 F.2d 43 (7th Cir. 1963), cert. granted, 375 U.S. 983 (1964) (review of discovery order for physical examination).

83 Life Music, Inc. v. Edelstein, 309 F.2d 242 (2d Cir. 1962) (per curiam). But sce Padovani v. Bruchhausen, 293 F.2d 546 (2d Cir. 1961) (trial court's use of pre-trial statement was in effect a demal of trial before a jury).

84 Regec v. Thornton, 275 F.2d 801 (6th Cir. 1960) (per curiam).

85 Pet Millk Co. v. Ritter, 323 F.2d 586 (10th Cir. 1963) (per curiam). 
appeal from a final judgment. ${ }^{86}$ It explains why, accepting the premise that expense and inconvenience to a litigant do not require interlocutory review, the courts refuse extraordinary review of transfer to an allegedly nore inconvenient district, since there is a distinct possibility that upon an appeal from a final judgment the aggrieved party will be unable to show that any error in the trial court's decision to transfer affected the outcome of the litigation in the transferee district. Sucli a showing would be necessary im order to warrant a retrial on the merits. ${ }^{87}$ Framing the problem in terms of efficient yet effective judicial administration also explains why a trial court's order of transfer to a district in which the action could not have been brought originally requires immediate review since there is an absolute certainty that the litigation will be carried on in a district in which venue has not been properly laid, thus requiring re-trial on the merits sliould there be an appeal from the final judgment..$^{88}$ This approach also explains why issues sucl as deprivation of the party's right to a jury trial, trial before the court, or trial before an impartial tribunal present controversies appropriate for interlocutory review. If the trial court has erred in these matters, there is absolute certainty that the action if appealed will be tried for a second time on the merits.

\section{IV}

\section{MLANDAMUS TO TEST PERSONAL JURISDICTION}

If circunivention of the rule of finality is approached in this manner, the conclusion is inescapable that the appellate courts err in refusing to review through extraordinary means the question of the court's jurisdiction over the parties to the action, especially in light of the greater possibility of trial court error since the decision in International Shoe v. Washington. ${ }^{89}$ Consider the plight of the corporate defendant in a federal court who in good faith contests the court's personal jurisdiction and loses. It then nust litigate the controversy on the merits, and is not

${ }^{86}$ The appellant must of course be able to show he has been prejudiced by an error in the trial court proceedings. However, because an issue is moot does not necessarily mean that the aggrieved party has not been harmed. Consider a trial court's refusal to allow the taking of a deposition, accompanied by the death of the party sought to be questioned prior to a final judgment. The issue of the availability of the desired discovery device has obviously become moot, but it may nevertheless have substantially affected the aggrieved party's ability to successfully litigate his cause. In California, review of a trial court's discovery order through extraordinary proceedings is available, though sparingly granted. Such use has evolved without the aid of legislative enactment. See generally LoUISEIL, MOdern CAIJFORNIA Discovert (1963) 37-41.

87 See Ford Motor Co. v. Ryan, 182 F.2d 329 (2d Cir.), cert. denied, 340 U.S. 851 (1950).

88 Olberding v. Tlinois Cent. R.R., 346 U.S. 338 (1953).

80 See note 65 supra. 
entitled to review of the trial court ruling on jurisdiction until appeal from a final judgment. Should the appellate court determine that the trial court erred, all prior hitigation is invahidated.$^{90}$ Certainly, relitigation on the merits could be avoided where immediate review of the trial court's ruling is available. It cannot be denied that immediate review in such a situation aids in the administration of justice, for though a burden is placed on the appellate courts, it is compensated by savings in time to the trial court. ${ }^{.1}$ There is, of course, the possibility of delaying tactics by litigants through frivolous petitions for extraordinary writs, but this is a possibility which the appellate courts can police by requiring litigants, in their briefs accompanying motions to petition, to make a clear showing that the possible trial court error demands immediate review.

In contrast to the present procedure in the federal courts for review of the trial court's determination on the question of personal jurisdiction, the California procedure of testing the jurisdictional question in the appellate courts at the outset of the litigation is far preferable. The California litigant, having made a special appearance and lost on the jurisdictional question, may within ten days petition an appropriate appellate court for writ of mandate to prevent the trial court from proceeding with the case. ${ }^{92}$ In this way, the litigants and the courts are assured that time and expense consunied in trial are not to be wasted as the result of a jurisdictional error. It may be argued that the California use of writs of mandamus in this fashion, unlike a similar use in the federal courts, is sanctioned by a legislative enactment, and that the federal courts should await the decision of Congress to expand the use of writs of mandanus to this area. The California practice however developed in spite of a statute incorporating the final judgment rule, ${ }^{93}$ and long before the California legislature chose to recognize the practice throughl legislative enactment. ${ }^{94}$

The expansion of the use of mandamus proceedings to test jurisdiction at the outset in the federal courts will in no way strain the current interpretation of the All Writs Act as enunciated in $L a B u y$ v. Howes Leather, and will contribute to the efficient functioning of the federal judicial system.

\section{A. James Roberts III}

90 E.g., Harkness v. Hyde, 98 U.S. 476 (1878).

01 See Padovani v. Bruchhausen, 293 F.2d 546 (2d Cir. 1961) where the court suggests that judicial economy is a valid consideration. See also Ex parte Skinner, 265 U.S. 86 (1924). 92 CaI. Code Civ. Proc. \& 416.3.

93 Cal. Code Crv. Proc. \& 963.

94 Jardine v. Superior Ct., 213 Cal. 301, 2 P.2d 756 (1931). 